\title{
Assessment of Student's Knowledge in high Institute of Medical Technology / Abuslim about Tuberculosis diseases
}

Hamida Mohammed Amer ( $\square$ dodeyamer@yahoo.com )

High Institute of Medical Technology

Amal Almasri Ouhida

High Institute of Medical Technology

\section{Research Article}

Keywords: student , TB , knowledge , bacteria

Posted Date: June 1st, 2021

DOI: https://doi.org/10.21203/rs.3.rs-567317/v1

License: (c) (1) This work is licensed under a Creative Commons Attribution 4.0 International License.

Read Full License 


\section{Abstract}

Objective: A purposive study aims to identify the student knowledge about tuberculosis disease.

Methods: The sample of 140 students was selected from the second, third, fourth, fifth and sixth class from the medical departments in high Institute of Medical Technology/abusleem for the period from March 2019 to June 2019.

The questionnaire was designed to achieve the aims of study, it was consisting of many parts, the first content the demographic information, the second part include knowledge of students about categories that infected with tuberculosis. The third part include the student knowledge of the signs of disease, the fourth content methods of transmission of disease, and the last part include the student information about the methods of protection of tuberculosis disease. Data were analyzed by using frequency distribution, percentage

Results: This study found insufficient TB knowledge in a sample of students, poor knowledge about TB. They must improve knowledge about TB, because these students could be exposed to the Mycobacterium strains during their training activities or when they are employed in private and public health care settings.

\section{Introduction}

Tuberculosis is an infectious disease caused by Mycobacterium tuberculosis. Tuberculosis typically attacks the lungs, but can also affect other parts of the body. The disease has become rare in high income countries, but is still a major public health problem in low- and middle-income countries (Rieder et al., 2009).

It is estimated that between the years 2000 and 2010, eight to nine million new cases emerged each year. Approximately 1.5 million people die from the disease each year. In adults, tuberculosis is the second leading cause of death due to an infectious disease (after AIDS), with $95 \%$ of deaths occurring in lowincome countries. Tuberculosis is a major problem of children in poor countries where it kills over 100,000 children each year (Michael, 2017; Edward, 2012).

Tuberculosis is an airborne disease caused by the bacterium Mycobacterium tuberculosis ( $M$. tuberculosis). M. tuberculosis and seven very closely related mycobacterial species (M. bovis, M. africanum, M. microti, M. caprae, M. pinnipedii, M. canetti and M. mungi) together comprise what is known as the M. tuberculosis complex (Rieder et al., 2009).

The human tubercle bacillus (Mycobacterium tuberculosis) is the main cause of tuberculosis all over the world. A slightly different type of TB, Mycobacterium africanum, occurs in Africa. The only important difference is that it is often resistant to thioacetazone (Rieder et al., 2009). 
The bovine bacillus (Mycobacterium bovis) at one time caused much infection in cattle in Europe and the Americas. Infection was often passed on to man through contaminated milk. Bovine TB in milk can be killed by boiling the milk, and bovine tuberculosis rarely occurs where this is the practice. The extent of the transmission of bovine tuberculosis to humans is difficult to determine because of technical problems in isolating the organisms. One important difference is the resistance to pyrazinamide in $\mathrm{M}$. bovis (Michael, 2017).

Diagnosing and initiating effective treatment in a patient early in the course of their TB disease, before they can infect many people, is considered the most effective preventive measure against TB. Effective treatment substantially reduces or eliminates disease transmission from smear-positive patients in less than one month after initiation of treatment (Packe \& Innes, 1988).

Before immunity is established, bacilli from the primary infectious focus or from a near-by lymph node can be transported and disseminated throughout the body via the lymph system or the bloodstream (Di Palma, 2011). Secondary foci containing bacilli can be born this way, particularly in the lungs, lymph nodes, serous membranes, meninges, bones and kidneys. As soon as an immune response is mounted, most of these foci spontaneously resolve. Yet, a number of bacilli may remain latent in the secondary foci for months or even years (Ait-Khaled \&Enarson, 2003)

In the majority of cases (90 to $95 \%$ of non-HIV infected patients), the pulmonary lesions gradually heal. In 5 to $10 \%$ of the cases, the pulmonary lesion will progress to active disease either by gradual progression and/or spread via lymphatics or blood or by reactivation (often many years later) of primary or secondary lesions (Di Palma, 2011)

\section{Materials And Methods}

The research procedure included the following:

1-Research sample:

The sample of 140 student was selected from the second, third, fourth, fifth and sixth class from the medical departments in high Institute of Medical Technology/Abuslim for the period from March 2019 to June 2019.

\section{2-Research Method:}

The questionnaire was designed to achieve the aims of study, it was consisting of many parts, the first content the demographic information, the second part include knowledge of students about categories that infected with tuberculosis. The third part include the student knowledge of the signs of disease, the fourth content methods of transmission of disease, and the last part include the student information about the methods of protection of tuberculosis disease.

3-Statistical Analysis: 
Data were analyzed by using frequency distribution, percentage to answer the level of (yes, No).

\section{Results:}

The most of the students were aged between (19-20) years and the highest of them were female (56.3\%) and most of them were single (85.7\%). knowledge of students about categories that infected with tuberculosis the most of student answered TB infects people whose have respiratory disease (89.3\%). Student knowledge of the signs of disease the most student answered TB patient has headache $(73.6 \%)$, while student answered the TB patient has Pain chest (10.7\%). The most student answered TB transmission through food, diary and dairy products $(73.6 \%)$, while $(14.2 \%)$ answered transmission of TB from mother to fetus. Student answered TB can transmission through sneezing and coughing from infected people to healthy people (41.4\%).

The most student answered for protection from TB avoid smoking (85.7\%), while (17.9\%) answered take preventive measures when contact with infected person.

\section{Conclusion}

This study found insufficient TB knowledge in a sample of students, poor knowledge about TB. They must improve knowledge about TB, because these students could be exposed to the Mycobacterium strains during their training activities or when they are employed in private and public health care settings.

\section{Declarations}

\section{ACKNOWLEDGMENTS}

We thank Abuslim higher institute of health sciences for funding this study.

The authors declare no competing interests.

\section{References}

Di Palma S. (2011) . Tuberculosis and the BCG Vaccine: Not Quite Good Enough. Science Creative Quarterly. Issue 6,.

Edward N (2012), personal communication, Partners In Health and Harvard School of Public Health, Boston USA, October.

Francis V, Michael L. (2017) Rich M6édecins Sans Frontières and Partners in Health. Tuberculosis: Practical guide for clinicians, nurses, laboratory technicians and medical auxiliaries.

Hans. Rieder, Chiang Chen, Yuan Robert . P. Gie ,Donald A.(2009) Enarson .Clinical Tuberculosis, Third Edition 
Iseman MD. (2000). A clinician's guide to tuberculosis. Lippincott Williams \& Wilkins;. pp.69.

Nadia Ait-Khaled, Donald A. Enarson. (2003). Tuberculosis: A manual for Medical Students. World Health Organization.

Packe GE, Innes JA. (1988). Protective effect of BCG vaccination in infant Asians: a case-control study. Arch Dis Child. BMJ Publishing Group Ltd and Royal College of Paediatrics and Child Health; 63(3):27781.

\section{Tables}

table 1 Demographic information 


\begin{tabular}{|c|c|c|}
\hline 1. semester & No. & Percentage \\
\hline Second & 13 & 9.29 \\
\hline third & 27 & 19.3 \\
\hline Forth & 44 & 31.4 \\
\hline Fifth & 36 & 25.7 \\
\hline Sixth & 20 & 14.3 \\
\hline total $=$ & 140 & \\
\hline 2. Department & No. & Percentage \\
\hline Medical laboratory & 20 & 14.3 \\
\hline Anesthesia and intensive care & 20 & 14.3 \\
\hline General nursing & 20 & 14.3 \\
\hline Midwifery & 20 & 14.3 \\
\hline Physiotherapy & 20 & 14.3 \\
\hline community health & 20 & 14.3 \\
\hline Pharmacy & 20 & 14.3 \\
\hline total $=$ & 140 & \\
\hline 3.Age & No. & Percentage \\
\hline $19-20$ & 95 & 67.9 \\
\hline $21-22$ & 38 & 27.1 \\
\hline $23-24$ & 07 & 05 \\
\hline total & 140 & \\
\hline 4.Sex & No. & Percentage \\
\hline Male & 61 & 43.6 \\
\hline Female & 79 & 56.3 \\
\hline total & 140 & \\
\hline 4. Does a family member have TB? & No. & Percentage \\
\hline Yes & 0 & 0 \\
\hline No & 140 & 100 \\
\hline total & 140 & \\
\hline 5.Are you single or married? & No. & Percentage \\
\hline single & 120 & 85.7 \\
\hline married & 14 & 10 \\
\hline divorced & 6 & 4.3 \\
\hline total & 140 & \\
\hline
\end{tabular}

table 2 knowledge of students about categories that infected with tuberculosis: 
1. Infects both sex

Yes

No

$$
\text { total }=140
$$

2.Infects female more than male

Yes

No

\begin{tabular}{l|r} 
& $\mathrm{N}$ \\
\hline & 123 \\
\hline & \\
\hline
\end{tabular}

\begin{tabular}{|c|c|}
\hline No. & Percentage \\
\hline 100 & 71.4 \\
\hline 40 & 28.6 \\
\hline
\end{tabular}

total $=140$

3.Infects people with respiratory disease

\begin{tabular}{l} 
Yes \\
\hline No
\end{tabular}

\begin{tabular}{c|c|}
\hline No. & \\
\hline 123 & \\
17 &
\end{tabular}

Percentage

87.9

12.1

$$
\text { total }=140
$$

4. Infects factory worker more than other

Yes
No

$$
\text { total }=140
$$

5.Infects staff in respiratory diseases hospital

Yes
No

$$
\text { total }=140
$$

j.Infects people with acquired immunodeficiency syndrome

Yes
No

$$
\text { total }=140
$$

7. Infects child whose mother is infected with the disease .

\begin{tabular}{l} 
Yes \\
\hline No
\end{tabular}

total

\section{Infects smoker more than other}

$$
\text { total }=140
$$

\begin{tabular}{l} 
Yes \\
\hline No
\end{tabular}

total = $=140$

$$
\text { total }=140
$$

\begin{tabular}{|c|c|c|c|}
\hline \multicolumn{4}{|l|}{ Yes } \\
\hline No & & & \\
\hline & total & $=$ & 140 \\
\hline
\end{tabular}

9.Infects family members with a person with disease

\begin{tabular}{lll}
\hline Yes & & \\
\hline No & & \\
\hline & total $=$ & 140
\end{tabular}

\section{0.infects children}

\begin{tabular}{ll} 
Yes \\
\hline No
\end{tabular}

11. It infects adult only?

total $=140$


table 3 Student knowledge of the signs of disease 
1. Is the disease accompanied with fever especially at night?

Yes

No

2. the TB patient has headache

Yes

Vo

total $=140$

total $=140$

3.The patient become tired when he make an effort

Yes

No

1.The patient losing weight

Yes

No

j. Night sweats occur

Yes

j.Pain chest occur

Yes

No

7.Patient has cough with blood and pus

Yes

3. The patient loses appetite

Yes

9.The patient has pallor

Yes

10. Patient has severe pain in the body?

Yes

No

Yes

$\begin{array}{lll}\text { total } & =140 \\ & & \\ & & \\ \text { total }= & 140\end{array}$

total $=140$

\begin{tabular}{c|c} 
No. & Percentag \\
\hline 19 & 13.6 \\
\hline 121 & 86.4 \\
\hline
\end{tabular}

No. Percentage

\begin{tabular}{c|c|}
\hline 103 & 73.6 \\
\hline 37 & 26.4 \\
\hline
\end{tabular}

\begin{tabular}{|c|c|}
\hline No. & Percentage \\
\hline 60 & 42.9 \\
\hline 80 & 57.1 \\
\hline
\end{tabular}

\begin{tabular}{|c|c|}
\hline No. & Percentage \\
\hline 63 & 45 \\
\hline 77 & 55 \\
\hline
\end{tabular}

\begin{tabular}{|c|c|}
\hline No. & Percentage \\
\hline 25 & 17.9 \\
\hline 115 & 82.1 \\
\hline
\end{tabular}

\begin{tabular}{|c|c|}
\hline No. & Percentage \\
\hline 15 & 10.7 \\
\hline 125 & 89.3 \\
\hline
\end{tabular}

\begin{tabular}{|c|c|}
\hline No. & Percentage \\
\hline 34 & 24.3 \\
\hline 106 & 75.7 \\
\hline
\end{tabular}


12.The patient is exposed to pneumonia

\begin{tabular}{l|r|r|}
\hline Yes & 93 & 66.4 \\
\hline No total $=140$ & 47 & 33.6 \\
\hline \multicolumn{3}{l|}{} \\
\hline
\end{tabular}

table 4 Methods of transmission of disease 


\begin{tabular}{|c|c|c|}
\hline Transmission through contaminated air and water & No. & Percentage \\
\hline$\overline{\mathrm{es}}$ & 90 & 64.3 \\
\hline o & 50 & 35.7 \\
\hline total & & \\
\hline Transmission through food, diary and dairy products & No. & Percentage \\
\hline es & 75 & 53.6 \\
\hline$\overline{\mathrm{O}}$ & 65 & 46.4 \\
\hline total & & \\
\hline Transmission through insects bite & No. & Percentage \\
\hline Yes & 100 & 71.4 \\
\hline No & 40 & 28.6 \\
\hline total & & \\
\hline Transmission from mother to fetus & No. & Percentage \\
\hline Yes & 20 & 14.2 \\
\hline No & 120 & 85.7 \\
\hline total & & \\
\hline 5. Transmission through contact with infected people & No. & Percentage \\
\hline Yes & 93 & 66.4 \\
\hline No & 47 & 33.6 \\
\hline total & & \\
\hline 6. Transmission through contaminated tools & No. & Percentage \\
\hline$\overline{Y e s}$ & 88 & 62.9 \\
\hline No & 52 & 37.1 \\
\hline total & & \\
\hline $\begin{array}{l}\text { Transmission through sneezing and coughing from } \\
\text { fected people to healthy people }\end{array}$ & No. & Percentage \\
\hline Yes & 58 & 41.4 \\
\hline No & 82 & 58.6 \\
\hline total & & \\
\hline Transmission in crowded place & No. & Percentage \\
\hline Yes & 97 & 69.3 \\
\hline No & 43 & 30.7 \\
\hline total & & \\
\hline Transmission in closed place & No. & Percentage \\
\hline Yes & 48 & 34.3 \\
\hline No & 92 & 65.7 \\
\hline total & & \\
\hline J.Increasing in people with weakened immune system & No. & Percentage \\
\hline Yes & 40 & 28.6 \\
\hline No & 100 & 71.4 \\
\hline total & & \\
\hline
\end{tabular}


table 5 Student information about the methods of protection of tuberculosis disease.

1.Early diagnosis

Yes

No

\begin{tabular}{|c|c|c|c|c|}
\hline & & & No. & Percentage \\
\hline & & & 68 & 48.6 \\
\hline & & & 72 & 51.4 \\
\hline total & $=$ & 140 & & \\
\hline & & & No. & Percentage \\
\hline & & & 40 & 28.6 \\
\hline & & & 100 & 71.4 \\
\hline
\end{tabular}

2. Avoided crowded place

Yes

No

total $=140$

3.If has symptoms go to doctor

Yes

No

\begin{tabular}{|c|c|}
\hline No. & Percentage \\
\hline 80 & 57.1 \\
\hline 60 & 42.9 \\
\hline
\end{tabular}

total $=140$

4.Ventilation of public people and crowded

Yes

j.Isolation of patient

yes

No

j.Take preventive measures when contact with infected person

Yes

7. Taking BCG vaccine

Yes
No

3. Provide good food

Yes

No

9. Playing sports

\begin{tabular}{l} 
Yes \\
\hline No
\end{tabular}

10.Avoid smoking

Yes

No

total $=140$

\begin{tabular}{l|r} 
& \\
total $=140$ & 110 \\
\hline
\end{tabular}

total $=140$

total $=140$

total $=140$

\begin{tabular}{|l|l|}
\hline & \\
\hline & \\
\hline
\end{tabular}

\begin{tabular}{c|c|}
\hline No. & \\
\hline 25 & \\
115 & \\
\hline
\end{tabular}

\begin{tabular}{|c|c|}
\hline No. & Percentage \\
\hline 55 & 39.3 \\
\hline 85 & 60.7 \\
\hline
\end{tabular}

\begin{tabular}{|c|c|}
\hline No. & Percentage \\
\hline 30 & 21.4 \\
\hline 110 & 78.6 \\
\hline
\end{tabular}

No. $\quad$ Percentage

82.1

\begin{tabular}{|c|c|c|}
\hline & No. & Percentage \\
\hline 70 & 50 \\
\hline 70 & 50 \\
\hline
\end{tabular}

